\title{
Trasa stého ročníku cyklistického závodu Giro d'Italia jako prostor k obnovování italské národní identity (i představení Itálie zahraniční veřejnosti) ${ }^{1}$
}

\section{The $100^{\text {th }}$ Edition of the Cycling Race Giro d'Italia and Its Route As a Space for the Restoration of Italian National Identity (As Well As the Presentation of Italy to Foreign Public)}

\author{
Jiří Zákravský \\ Fakulta filozofická, Západočeská univerzita v Plzni
}

\begin{abstract}
Abstrakt
Již od roku 1909 a vzniku Gira d'Italia, závodu v silniční cyklistice napřič Itálií, je možné hovořit o velké popularitě této sportovní akce zejména, ale nikoliv pouze, na italské půdě. Někteří autoři dokonce s trochou nadsázky upozorňuji, že právě konání Gira d'Italia udělalo pro vytvořeni společné italské identity více než samotní političtí predstavitelé státu, který se zrodil v roce 1861. Jako důkaz této popularity může sloužit skutečnost, že se v roce 2017 uskutečnil již stý ročník závodu. Jeho pořadatelé se v dưsledku tohoto jubilea snažili o to, aby bylo sté Giro celoitalským podnikem, v němž budou zřetelně viditelné odkazy na historii Itálie a úspěchy tamní cyklistiky včetně opětovného představení nejslavnějších italských závodníků. Cílem tohoto článku je analyzovat samotnou trasu závodu a její prezentaci jako prostredí, které by mělo v mistních podnítit uvědomování si jejich (potenciální) italské identity, i kdyby $v$ roce 2017 tamní cyklisté nebyli tak úspěšní, jak si pořadatelé Gira přáli. Zároveň hodlám upozornit na fakt, že ve druhé dekádě 21. století je tento cyklistický podnik jednoznačně událostí, která má potenciál prèedstavit nejenom Giro d'Italia, ale s ním i celou Itálii v co nejpozitivnějším světle zahraniční veřejnosti. Tento cyklistický závod je tak určitě možné využívat jako nástroj italské sportovní diplomacie.
\end{abstract}

\begin{abstract}
It is possible to say that Giro d'Italia, the road cycling race through Italy, has had a huge popularity mainly, but not exclusively, among the Italians since it was held for the first time in 1909. Some authors even mention, Giro d'Italia did for the formation of the common Italian identity more than the political representatives of the state, which was born in 1861. The fact that the $100^{\text {th }}$ edition of the race took place in 2017 is the proof of its popularity. In the context of this anniversary, its organizers wanted to prepare the wholly Italian race where it would be clearly observed the legacy of the Italian history and of the local cycling, including the presentation of the most famous cyclists from Italy in the history. The aim of this article is to analyse the route of Giro d'Italia 2017 and its presentation as a space that could help to Italians to recognize their Italian identity, even if the local cyclists were not as successful during the $100^{\text {th }}$ edition of the race as the organizers would have wished. Also I would like to mention that in the second decade of the $21^{\text {st }}$ century this cycling race is definitely a popular sporting event all around the world. Not only it has a potential to present itself to the foreign public, but also to promote whole Italy in the most positive way. I think, it is certainly possible to use Giro d'Italia as a tool of the Italian sports diplomacy.
\end{abstract}

\footnotetext{
${ }^{1}$ Tento článek vznikl jako součást projektu „Proměny světového regionalismu“ (SGS-2016-027) podpořeného $\mathrm{v}$ rámci Studentské grantové soutěže ZČU v Plzni.
} 
Klíčová slova: Giro d'Italia, cyklistika, nacionalismus, banální nacionalismus, Itálie, sportovní diplomacie.

Keywords: Giro d'Italia, cycling, nationalism, banal nationalism, Italy, sports diplomacy.

\section{ÚVOD}

Sport se během 20. století stal masově rozšířenou aktivitou. V tomto smyslu je možné uvažovat jak o jeho praktikování ze strany veřejnosti, tak i o pasivním sledování výkonů (profesionálních) sportovců. Informace o sportovních výsledcích, rozhovory spojené s tímto tématem apod. jsou pro mnohé koloritem každého dne, přičemž se o nich lidé dozvídají z mainstreamových médií i jsou informováni prostřednictvím stále častěji užívaných internetových sociálních sítí. Mnohdy byla média dokonce tím, kdo stál za pořádáním určitých sportovních soutěžení. Skutečnost, že se média ujala role organizátora konkrétní sportovní akce, vycházela často z jejich snahy udělat si reklamu, která bude v konečném důsledku znamenat ekonomický zisk.

Právě díky tomu vznikla Tour de France, pod níž jsou podepsány noviny L'Auto. Že se jednalo o dlouhodobě úspěšný projekt, je zřejmé, neboť v roce 2017 se uskutečnil 104. ročník závodu. Je však nutné zmínit i okamžitou úspěšnost této atypické reklamní kampaně, nebot’ v den poslední etapy premiérové Tour de France v roce 1903 se prodalo okolo 130000 výtisků L'Auto, což znamenalo oproti předchozím dobám nárůst o více než 100000 kusů (McGann \& McGann, 2006, s. 10). Obdobným způsobem se zařídil italský deník La Gazzetta dello Sport v roce 1909, který se rozhodl uspořádat cyklistický závod napřič Itálií po francouzském vzoru. V následujících letech se několikadenní soupeření cyklistů zakládala i v dalších místech starého kontinentu, třetí z nyní nejvýznamnějších etapových závodů však vznikl na španělské půdě až v roce $1935 .{ }^{2}$

Zároveň je nutné si uvědomit, že veškeré tyto etapové závody jsou spojeny s formováním a vyjednáváním národní identity místních, kteří danou sportovní akci sledují, přičemž není podstatné, zda se nachází př́mo v místě konání závodu či stovky kilometrů od něj, ale dostávají informace zprostředkovaně ze strany médií. Sledují tak trasu, již závod prochází, přejí favoritům na celkové umístění, i cyklistům, kteří bojují za menší úspěchy v každé etapě, a potleskem (většinou) odmění vítěze i poražené. A také vědí, že za rok se tento závod na „jejich“ silnice vrátí. Německý spisovatel a sportovní žurnalista Hans Blickensdörfer v románu Sůl v kávě, který se odehrává během dvou ročníků Tour de France, v této souvislosti vkládá jednomu z hrdinů knihy do úst, když vysvětluje, proč je Tour tak sledovaná, následující myšlenku: „Nahlíženo racionálně, není to [tzn. samotný závod] pro svět důležité, ale vyroste z toho emocionální Mount Everest“" (Blickensdörfer, 1985, s. 210). Právě emoce spojené se sportovním zápolením jsou něčím, co „nenásilným“ způsobem nutí místní na Tour de France uvědomit si svou francouzskou identitu či jsou takto Italové každý květen již více než sto let upozorňováni na své „italské já“.

Cílem tohoto textu je analyzovat stý ročník italského cyklistického podniku Giro d’Italia, respektive jeho trasu a její prezentaci jako prostředí, které by mělo v místních podnítit uvědomování si jejich (potenciální) italské identity. Stý ročník závodu okolo Itálie pořádaný v roce 2017 měl vstoupit do historie jako „celoitalský závod“, který by měl navštívit co možná největší množství italských oblastí, přičemž taktéž neopomíjel, jak upozorňoval ředitel závodu Mauro Vegni, odkazy na „[...] historii Itálie a obzvláště Giro d’Italia“ (Vegni cit. dle Farrand, 2016). Je však nezbytné si uvědomit, že Giro takovýmto způsobem již - také v důsledku rozvoje médií - nekomunikuje

\footnotetext{
${ }^{2}$ Již předtím se na Pyrenejském poloostrově pořádaly etapové závody, které existují dodnes. Jedná o závod okolo Katalánska (Volta Ciclista a Catalunya) či okolo Baskicka (Vuelta al País Vasco - Euskal Herriko Itzulia), na jehož založení se podílel sportovní deník Baskické nacionalistické strany Excelsior. Podrobněji o prvním ročníku závodu okolo Španělska viz (López, 2010).
} 
pouze se samotnými Italy. $\mathrm{O}$ italských památkách či přírodě a tamních (sportovních) hrdinech v neposlední řadě se dozvídají sledováním tohoto závodu také cyklističtí fanoušci ze zahraničí.

První část textu bude věnována $v$ teoretické rovině nacionalismu a jeho propojení se sportem. V této pasáži kromě jiného stručně představím tzv. banální nacionalismus, tj. koncept, který popsal v polovině 90. let britský sociolog Michael Billig (1995). Druhá kapitola se zabývá samotným stým ročníkem závodu okolo Itálie a je v ní kladen důraz na trasu, jíž Giro d’Italia v roce 2017 procházelo. Zaměřím se tedy na to, jaká z pro Itálii a tamní cyklistiku významných míst byla zvolena pro průjezd pelotonu v kontextu tohoto kulatého výročí závodu a na jejich odůvodnění ze strany pořadatelů. Již samotná trasa stého ročníku měla, jak se budu snažit dokázat, vyvolat mezi Italy pocit sounáležitosti, i kdyby všichni z domácích závodníků zůstali v každé etapě podniku hluboko v poli poražených. ${ }^{3}$

\section{SPORT (A NEJENOM CYKLISTIKA) VE SLUŽBÁCH NACIONALISMU}

K šírení prvotních myšlenek o existenci národa ${ }^{4}$ či později opětovné uvědomování národní identity je do jisté míry spojeno i se sportem. Ten totiž kromě ideálů fair-play nebo emocí spojených s měřením sil ve všech možných disciplínách s sebou velmi často přináší i neprrímý odkaz na existenci národa, jehož členové si společně se sledováním sportovního dění na místě jeho konání či prostřednictvím různých médií mohou uvědomovat, že jsou tohoto národa součástí.

V této souvislosti je vhodné zmínit tzv. banální nacionalismus. S nacionalismem, jemuž dává Michael Billig (1995) přízvisko banální, se totiž setkáváme prakticky každý den, přičemž se tak děje $\mathrm{v}$ prostorech, o kterých a priori nepředpokládáme, že bychom ho zde mohli hledat. Zároveñ tedy je možné říci, že nacionalismus působí na nositele či potenciální nositele dané identity jakousi skrytou formou. Tzn., že „[b]anální nacionalismus je nalézán ve zprávách o počasí, na sportovních stránkách [novin] a zavěšený zplihle na vlajkách v prostorách čerpacích stanic“ (Billig, 1995, s. 155). Sport se tak nejenom dle tohoto autora jeví jako vhodný prostředek, který povede $\mathrm{k}$ podvědomému přihlášení se $\mathrm{k}$ národu. To platí zejména $\mathrm{v}$ okamžiku, kdy dochází $\mathrm{k}$ široce medializovaným mezinárodním střetnutím. Je tedy možné říci, že „[s]myšlené společenství miliónů se zdá skutečnější, má-li podobu týmu jedenácti lidí s konkrétními jmény“ (Hobsbawm, 2000, s. 139). Pomyslné společenství tak na sebe vezme podobu reprezentačního výběru či konkrétního jednotlivce, který se stává ztělesněním národa. To, jak jsou tento tým či jednotlivec úspěšní ve světě sportu, je v symbolické rovině rovno úspěchu samotného národa, což by v ideálním př́ipadě mělo vést k posílení národní identity u „domácích“ fanoušků úspěšných sportovců i pozitivní percepci daného národa $\mathrm{v}$ zahraničí.

Jak úspěchy sportovních reprezentantů národa působí na společnost, popisuje de facto sám na sobě i výše zmiňovaný Michael Billig (1995, s. 135), který uvádí, že

\footnotetext{
${ }^{3}$ Italští cyklisté získali na stém ročníku svého domácího závodu pouze jedno etapové vítězství, o které se postaral až v šestnácté etapě obhájce celkového prvenství z předchozího roku Vincenzo Nibali. Nakonec byl také nejlepším Italem v konečném pořadí, když obsadil třetí přičču.

${ }^{4} \mathrm{O}$ národu uvažuji obdobným způsobem, který představil Benedict Anderson, tj. jako o tzv. pomyslném společenství (imagined community). Národ pro mne tedy je - ve shodě s výše zmíněným autorem - „,...] pomyslný, protože příslušníci i toho nejmenšího národa většinu ostatních členů nikdy nepoznají, nikdy se s nimi nesetkají a ani o nich nikdy neuslyší, přesto však v mysli každého $\mathrm{z}$ nich žije představa jejich společenstvi“ (Anderson, 1991, s. 6; překlad dle Anderson, 2003, s. 243-244; kurziva v originálu). To však neznamená, že pokud jednou dojde $\mathrm{k}$ „vytvořeni““ takového národa, pocit sounáležitosti mezi jeho členy bude trvalého rázu a přetrvá po generace. Naopak je třeba ho obnovovat, $\mathrm{k}$ čemuž kromě jiného slouži např. výuka ve školách.
} 
[k]dyž člověk z mé vlasti běhá rychleji nebo skáče výše než cizinci, cítím potěšení. Nevím proč. Chci, aby národní tým porážel týmy jiných zemí, střílel více branek, [rychleji] běhal nebo cokoli jiného. Mezinárodní zápasy se zdají být mnohem důležitější než domácí. Je zde nadstandardní vzrušení ze soupeření s něčím nepopsatelným v sázce.

Oním „nepopsatelným v sázce“ je něco, co by bylo možné označit za národní hrdost, respektive za posílení národní identity těch, kteří sportovní klání svých reprezentantů sledují či jsou o nich informováni. Tento stav tedy, pokud bych měl shrnout předchozí řádky do jedné věty, znamená, že (mezinárodní) sport disponuje schopností „[...] podpořit konstrukci národa, který je pomyslným“ (Cronin \& Mayall, 2005, s. 2).

V prrípadě cyklistických závodů okolo určitého národně definovaného území však může takové pocity vyvolat pouze skutečnost, že dojde ke konání samotného závodu. Domácí sportovci poté nemusí nutně náležet mezi jeho vítěze či ústřední protagonisty. Odpověd’ na otázku, proč tomu tak je, předkládá Anne-Marie Thiessová (2007, s. 215), když způsob, jakým jsou „okružní cyklistické závody“ vnímány, popisuje na Tour de France:

Sice šlo o [...] trápení [závodníků] a výkon nohou, ale ty byly prostředkem hromadného putování křížem krážem po důvěrném národním území. $Z$ nekonečných rovin oslepujícího vedra, $\mathrm{z}$ alpských sedel a propastí, $\mathrm{z}$ pobřežních srázů se stávaji kulisy každoročně znova začínaného hrdinského eposu, jehož autorství na sebe berou sportovní novináři. Davy diváků mačkajících se podél trasy, aby zatleskali závodníkům, připomínají výjev z nějaké velké opery, kde sbor pěje oslavnou píseň ke chvále národní jednoty [...].

Stejným způsobem by měli v ideálním případě z hlediska šíření nacionalistických myšlenek hledět na závod okolo svého národního území i Italové, kteří se nemusí nikam za cyklistickým pelotonem vydávat a ještě za jeho sledování něco platit. Naopak cyklisté sami zamíŕí takřka před práh jejich domu, což taktéž přispívá k popularitě takového typu sportovních zápolení (Cardoza, 2010, s. 355). Následující část textu již bude věnována poslednímu ročníku Gira d'Italia, jež takto přivítaly tisíce a tisíce Italů.

\section{GIRO D'ITALIA A JEHO STÝ ROČNÍK}

V oficiálním propagačním videu Gira d'Italia pro rok 2017 pojmenovaném Přiběh stého ročníku (La storia di 100 edizioni), které bylo představeno společně s trasou závodu koncem října 2016, zaznívá věta, že Giro je „[...] symbolem sjednocujícím Itálii““ (Giro d’Italia, 2016c). Nutno dodat, že Itálie ve druhé dekádě 21 . století je o poznání jednotnější, než tomu v předminulém století. Když nakonec byla idea risorgimenta dokonána a v roce 1861 se nezávislá Itálie stala skutečností, byt ještě nikoliv $\mathrm{v}$ teritoriu, $\mathrm{v}$ jakém ji známe dnes, nemohl ještě nikdo hovořit o existenci italského národa. Liberální politik Massimo d’Azeglio po dokončení risorgimenta prohlásil: „Stvořili jsme Itálii, nyní musíme stvořit Italy“ (d’Azeglio cit. dle Clark, 1996, s. 30). S trochou nadsázky je možné - s odkazem na jednu $\mathrm{z}$ nejnovějších knih o historii tohoto závodu od irského publicisty Colina O’Briena (2017) - říci, že to, co se nepodařilo tehdejším politickým představitelům, dokázal právě cyklistický peloton, který každoročně od roku $1909^{5}$ putuje např́íc Itálií, a to nejenom na Apeninském poloostrově. Giro d'Italia se v době své premiéry stalo italskou „,...] první opravdu národní sportovní událostí“ (Cardoza, 2010, s. 357).

Vrat̉me se však k poslednímu ročníku Gira. Při jeho představování se ředitel závodu Mauro Vegni nechal slyšet, že sté Giro d'Italia „[...] bude odrážet historii závodu i naší země. Bude to Giro plné překvapení i kvůli místům, která navštívíme. Místům, kde se psala historie samotné

\footnotetext{
${ }^{5}$ Výjimkou byla pouze léta, v nichž se konaly první a druhá světová válka, což je taktéž důvod, proč stý ročník podniku připadl až na rok 2017 a nikoliv již na rok 2009.
} 
Itálie“ (Vegni cit. dle Tomíček, 2017, s. 130). Závod tak snad ani nemohl začínat jinde než na Sardinii, ${ }^{6}$ odkud v 19. století zamíŕila vojska vedená revolucionářem Giuseppe Garibaldim dobývat Království obojí Sicílie. Tato skutečnost byla oznámena již v září 2016, přičemž bylo připomínáno, že závod Sardinií poprvé procházel již v roce 1961, který byl spojen s oslavami sta let od vzniku Itálie (Giro d'Italia, 2016b). Na Sardinii se tehdy uskutečnila jedna etapa, ve které si připsal své jediné vítězství na tomto závodě Ital Oreste Magni. O třicet let později tento ostrov dokonce přivítal první etapy závodu a, jak samotní pořadatele na podzim 2016 připomínali, uskutečnila se zde „[...] nezapomenutelná týmová prezentace na italské letadlové lodi Giuseppe Garibaldi“ (Giro d'Italia, 2016b). Ostatně jméno slavného bojovníka za právo národů - nejenom italského na sebeurčení v kontextu Gira d'Italia zaznívá z mnohých stran. Např. i oficiální průvodce závodem se základními informacemi o etapách apod. je pojmenován Garibaldi ${ }^{7}$ s odkazem na tohoto „[v]ousatého hrdinu, symbol sdíleného italství, jehož je Giro také nepopiratelnou součástí [...]“ (Monti, 2017, s. 5). Ostatně ředitel deníku La Gazzetta dello Sport Andrea Monti (2017, s. 5) samotný závod napřič Itálií ke Garibaldimu a jeho činům přirovnává: „Stejně jako Garibaldiho červená košile růžová ${ }^{8}$ nit Gira opětovně tento rok sešije [Itálii] v jednotnou zemi v těžkých časech krize a rozporů, překročí moře, přistane na ostrovech, vynoří se z jihu, aby dobyla sever a jeho hory a rozpletla se v Milánu [...]“.

\subsection{Nesmrtelní cyklističtí hrdinové Itálie a jejich odkaz v roce 2017}

Garibaldi však není jediným slavným Italem, jenž by byl se stým Girem spojován. Těmi dalšími jsou cyklistické legendy, novodobí hrdinové, kteří se proslavili svými sportovními výkony na nejslavnějším etapovém závodu pořádaném na italské půdě. Jak upozorňuje Allen Guttmann (1977, s. 55), „[j]akmile se bohové vytratili z Olympu nebo z Dantova ráje, nemusíme si je více usmiřovat nebo zachraňovat své duše, ale můžeme ustanovit nové rekordy. To je jedinečně moderní forma nesmrtelnosti“, tj. té věčnosti, na kterou někteří cyklisté z řad Italů určitě dosáhli. Ve výše zmiňovaném videu Př́běh stého ročníku je stručně představeno hned deset Italů, ${ }^{9}$ kteří psali historii tohoto závodu (Giro d'Italia 2016c).

Nejprve je zmiňován Costante Girardengo, vítěz Gira z let 1919 a 1923, který byl označován za „první italskou celebritu ze světa sportu“ (Cardoza, 2010, s. 364). Dodnes o jeho cyklistickém umění kolují legendy také $\mathrm{v}$ souvislosti s jeho přátelstvím $\mathrm{z}$ dětství s anarchistou a proslulým banditou Sante Pollastrim. Tento př́běh pronikl i do italské popkultury, když na počátku 90 . let vznikal píseň Bandita a šampión (Il Bandito e il Campione) nazpívaná Francescem De Gregorim. Součástí refrénu je následující verš odkazující na Girardengovy cyklistické schopnosti: „Jed’, Girardengo, jed’, velký šampióne, nikdo ti na silnicích nestačí. Dále pořadatelé zmiňují Alfreda Bindu, který jako první v historii na Giru celkově zvítězil pětkrát, či odkazují na Fiorenza Magniho. Na oficiálním videu tohoto cyklistického podniku pro rok 2017 se objevují pravděpodobně nejslavnější záběry spojené s tímto závodníkem z časovky Gira v roce 1956, do níž nastoupil se zlomeninou klíční kosti. Aby bylo jeho kolo stabilní a ulevil fraktuře, měl k řídítkům připevněnou gumu, kterou držel v zubech. Stejně tak pořadatelé na videu vzpomněli na Felice Gimondiho, jemuž byla

\footnotetext{
${ }^{6}$ Viz mapu s trasou stého Giro d'Italia v př́loze č. 1.

${ }^{7}$ Toto označení pro průvodce závodem, který je vydáván pravidelně od roku 1909, vzniklo v roce 1961, kdy bylo ústředním tématem Gira d'Italia stoleté výročí sjednocení Itálie (Monti, 2017, s. 5).

${ }^{8}$ Odkaz na růžovou nit vychází z podoby trikotu vedoucího cyklistiky tohoto závodu. Jeho barva je od roku 1931 růžová, přičemž byla vybrána v důsledku barvy papíru, na kterém se tiskly noviny závod pořádající.

${ }^{9}$ Spolu s nimi jsou jmenováni nejúspěšnější cyklista v historii a pětinásobný vítěz Gira z Belgie Eddy Merckx, Francouz Bernard Hinault triumfující na Giru během 80. let třikrát a Miguel Indurain ze Španělska, jenž zatím jako poslední cyklistika dokázal své celkové vítězství v závodě obhájit (Giro d’Italia, 2016c).
} 
věnována patnáctá etapa Gira v roce 2017, ${ }^{10}$ a Giuseppe Saronniho. Jmenováni jsou i Francisco Moser či excentrický sprinter Marco Cipollini, jenž zvítězil v nejvíce etapách v historii italského závodu. ${ }^{11}$ Přední pozornost se však v souvislosti s podobou trasy Gira zaměřovala na trojici Gino Bartali, Fausto Coppi a Marco Pantani.

Gino Bartalimu byla věnována jedenáctá etapa závodu, která - jak upozorňovali pořadatelé „[...] začínala v jeho rodném městě sedmnáct let po jeho úmrti““ (Giro d'Italia, 2016a). Tímto městem byla Florencie, respektive ostrý start proběhl v Ponte a Ema, kde se nyní nachází Cyklistické museum Gina Bartaliho. Jednalo se o etapu, která měřila 154 kilometrů, a závodníci v ní museli zdolat několik vrcholů Apenin. Oficiální průvodce závodem o ní hovořil jako o té, „[...] kde by Gino Bartali, pokud by tu stále byl, zaútočil“ (Montali, 2017, s. 227). Kým však byl tento závodník, k němuž se stoleté Giro d'Italia častokrát vracelo?

Bartali závodil mezi léty 1935 až 1953 a na Giru zaznamenal kromě jiného tři celková vítězství. Před i po druhé světové válce byl médii vykreslen a následně i vnímán společností jako „perfektní křestanský atlet“. Tuto image mu vytvořil katolický tisk na základě článku vzniknuvším v roce 1936, v němž se psalo o Bartaliho hluboké víře. Právě cyklistika se jevila jako vhodná metafora pro „zápas“ o život věčný. Také cyklistika - stejně jako život pozemský - je plná odříkání či bolesti, nicméně odměnou za to je vytoužená nesmrtelnost (Pivato, 1996, s. 131-133). Pro politické účely byl Bartali využíván taktéž po konci druhé světové války, kdy se „[...] rychle stal téměř kultovní postavou nastupujícího křestanskodemokratického hnutí [...]“ (Pivato, 1996, s. 134), s níž se rádi nechali vidět a fotografovat významní představitelé italského politického života v čele s Alcidem De Gasperim či Giuliem Andreottim a on sám doporučoval Italům, aby ve volbách právě křest̉anské demokraty podpořili (Pivato, 1996, s. 134-135). Také se tvrdí, že Bartaliho vítězství na Tour de France v roce 1948 částečně zachránilo Itálii od občanské války, ke které se patrně schylovalo v důsledku neúspěšného atentátu na lídra tamní komunistické strany Palmira Togliattiho. Údajně Bartalimu do Francie telefonoval tehdejší premiér De Gasperi, který ho požádal, aby se snažil tento závod pro Italy vyhrát. Nicméně je velmi pravděpodobné, že takový telefonát se nikdy neuskutečnil a jedná se o moderní mýtus (Foot, 2011, s. 134-135), v němž opětovně došlo k propojení italských politických dějin s těmi cyklistickými. Na druhou stranu dle bývalého mnohonásobného předsedy vlády Itálie Giulia Andreottiho (cit. dle Kratochvíl, 2009) sice „[ř]íct, že občanskou válku odvrátilo vítězství Bartaliho, je přehnané. Ale je neoddiskutovatelné, že jeho triumf uklidnil napětí v zemi“. Znovu se pro mnohé stal Bartali vzorem ve 21 . století, kdy se objevily důkazy o jeho aktivitách během druhé světové války. V ní se zapojil do činnosti ilegální organizace, která pomáhala židovskému a dalšímu perzekuovanému obyvatelstvu. V ní Bartali působil jako kurýr, který přepravoval dokumenty schované v rámu a řídítkách svého kola prakticky po celé Itálii. Tato kapitola Bartaliho života byla prakticky neznámá, nebot on sám o ní nikdy př́liš nehovořil a nechtěl, aby se o ní více vědělo, což přiznává i jeho dcera Andrea: „Když jsem se zeptala svého otce, proč bych o tom nikomu neměla říkat, povídal mi: ,Musíš dělat dobré věci, ale nesmíš o nich mluvit. Když o nich mluvišš, těžíš z neštěstí ostatních pro svůj vlastní prospěch“" (Bartali cit. dle Crutchley, 2014). Také příběh o tomto italském hrdinovi byl díky stému závodu napřič Itálií a jeho jedenácté etapě opětovně vyprávěn.

Bartaliho největším soupeřem byl o pět let mladší Fausto Coppi, jenž nakonec celkově zvítězil ve 40. a 50. letech pětkrát na Giru a dvakrát triumfoval i na Tour de France. Jejich „[...] rivalita se stala nejpopulárnějším elementem italské poválečné sportovní mytologie“ (Pivato, 1996, s. 129).

\footnotetext{
${ }^{10}$ Po jejím skončení tento bývalý cyklista předával cenu určenou vítězi této etapy, jímž se stal Lucemburčan Bob Jungels.

${ }^{11}$ I na něj bylo vzpomenuto přímo během závodu, kdy např. oficiální twitterový účet Gira d’Italia připomínal v souvislosti s etapou uskutečněnou 15. května, že před čtrnácti lety zvítězil Cipollini ve své poslední etapě Gira v životě (Giro d'Italia, 2017c).
} 
Výkony této dvojice cyklistů ${ }^{12}$ na závodech na italské půdě i mimo ni byly zahraniční veřejností hodnoceny pozitivně a vedly tak k vnímání Itálie, která stála v nedávno skončené druhé světová válce na straně poražených, v pozitivnějším světle (Cardoza, 2010, s. 372). Bartali, jak již zaznělo, byl chápán jako zástupce křest’anského demokratického proudu, naopak Coppi byl nejprve prezentován jako jeho protipól. Vítězství Coppiho nad Bartalim byla lidmi vymezujícími se proti církvi vnímána jako „[...] triumf ,mládí nad ,stářím', ,změnou' nad ,tradicí, ,pokrokem“ nad ,pověrčivosti'““ (Pivato, 1996, s. 136). Takto byl Coppi prezentován zejména ze strany komunistů, byt’ od 50. let, kdy se stal úspěšnějším závodníkem než jeho soupeř, o něm pozitivně začal smýšlet také katolický tisk a objevovaly se dokonce jeho časté fotografie s papežem Piem XII. Na druhou stranu jeho „líbánky“ s církví neměly dlouhého trvání, za což v silně katolické Itálii mohla jeho milostná aféra s „dámou v bílém“ Giuliou Occhini. Fausto Coppi tak byl vnímán - v kontrastu s Bartalim jako „cyklista d’áblův“, respektive jako „šampion komunistů“ (Pivato, 1990, s. 181-184). Životní př́běh italského cyklistického hrdiny skončil $\mathrm{v}$ jeho čtyřiceti letech, kdy podlehl malárii, kterou onemocněl během pobytu v Burkině Faso.

S Coppim byla spojena třináctá i čtrnáctá etapa závodu. ${ }^{13}$ První z nich končila ve městě Tortona, $\mathrm{v}$ němž tento slavný cyklista zemřel, a etapa následující naopak začínala $\mathrm{v}$ jeho rodné vesničce Castellania, kde se také tyčí Coppiho socha a nachází se zde jeho rodný dům a muzeum věnované tomuto cyklistovi. Na oficiálním twitterovém účtu závodu byla před startem této etapy zveřejněna např. fotografie vedoucího muže závodu - a o pár dnů později také jeho celkového vítěze - Nizozemce Toma Dumoulina stojícího v růžovém dresu před hrobkou Fausta a Sersea Coppiho $^{14}$ (Giro d'Italia, 2017a). Došlo tak k symbolickému setkání mezi legendou italské cyklistické historie s hvězdou současného pelotonu.

Ostatně trasa čtrnácté etapy byla i symbolickým spojením mezi italskou cyklistikou dob Coppiho a druhou polovinou 90. let. V roce 1998 ovládl jak Giro, tak Tour de France vrchař Marco Pantani. Díky těmto výkonům se z něj stal „[z]ávodník, který pro Italy opět objevil cyklistiku, vrátil na výsluní popularity sport, o kterém se zdálo, že už nikdy nebude lidi zajímat a probouzet u nich takové vášně, jaké probouzel kdysi u předchozích generací. Pantani pronikl do srdcí mladých [...]“ (Ronchi \& Josti, 2007, s. 52). Právě jemu byl tak věnován dojezd etapy začínající v Coppiho domově. Tato 131 kilometrů dlouhá etapa končila výjezdem do Oropy, kde se dle oficiálního průvodce italského závodu „[...] vznáší neklidný duch Marca Pantaniho“ (Monti, 2017, s. 5). V patnácté etapě Gira v roce 1999, jejiž cíl byl taktéž v Oropě, totiž tento cyklista triumfoval nevšedním způsobem, kdy se po mechanických problémech na začátku stoupání musel vracet zpět do startovního pole, přičemž nakonec předjel několik desítek závodníků před sebou a získal vítězství v etapě. Pantaniho prvenství z roku 1999 je vnímáno jako jedna z nejvěhlasnějších výher v novodobé historii Gira, a tak nutně „muselo“ být připomenuto při jeho stém ročníku.

\footnotetext{
${ }^{12} \mathrm{~V}$ souvislosti s těmito dvěma slavnými postavami italské cyklistiky vytvořila ke stému Giru italská společnost Santini dlouhodobě šijící oficiální trikoty závodu dvojici speciálních dresů, které měly připomínat tyto dva závodníky a jejich působení na závodu okolo Itálie (Fisher, 2017). Prakticky každý italský amatérský cyklista se tak může obléknutím Bartaliho/Coppiho dresu identifikovat s velikány tamní cyklistiky.

${ }^{13}$ Nebylo to však naposledy, kdy bylo vzpomínáno jméno Fausta Coppiho během závodu. Speciálním oceněním pro závodníka, který je nejrychlejším na nejvy̌̌ším vrcholu daného ročníku Giro d'Italia, je tzv. Cima Coppi odkazující na jednoho z nejslavnějších italských cyklistů všech dob. Uděluje se již od roku 1965 a v roce 2017 byla spojena s šestnáctou etapou, ve které se poprvé v historii vyjiždělo hned dvakrát na vrchol Passo dello Stelvio, kde se nachází památník věnovaný Coppimu. Právě na tomto stoupání v roce 1953 Coppi přemohl dosavadního lídra závodu Švýcara Huga Kobleta a o den později mohl v Miláně slavit celkové vítězství. Tento Coppiho počin byl např. připomínán ředitelem závodu Maurem Vegnim poté, co byla zveřejněna trasa stého Gira (Farrand, 2016).

${ }^{14}$ Serse Coppi byl stejně jako jeho starši bratr cyklistou. Na následky zranění, která utrpěl při pádu během závodu Giro del Piemonte, zemřel v 28 letech.
} 
První cyklista, který protal v Oropě pomyslnou cílovou pásku v roce 2017, zároveň triumfoval v tzv. Montagna Pantani, což je ocenění připomínající Pantaniho schopnosti v horách. Jedná se o vrchařskou soutěž vyhlašovanou každý rok od sezóny 2004 a je spojena s určitým významným vrcholem, jímž peloton na závodě okolo Itálie projiždí.

Život Marca Pantaniho, přezdívaného Pirát podle šátku, který pravidelně nosíval, skončil ještě dříve než Fausta Coppiho. Zemřel v roce 2004 ve 34 letech, jeho smrt byla způsobena pravděpodobně předávkováním návykovými látkami. $V$ rámci stého ročníku závodu si ho však připomněli i ti, kteří jeho slavná vítězství nemohou pamatovat. V levém horním rohu puzzly určeným dětem, na kterých je zobrazena komiksovým způsobem mapa závodu, je na mráčku společně s dalšími cyklistickými legendami minulosti vyobrazena postavička s šátkem a pirátskou vlajkou (Giro d'Italia Official Store, 2017).

\subsection{Slavná místa a trasa závodu (i jako „vábnička“ pro „ne-Italy“)}

Trasa stého Gira d'Italia nakonec nesměřovala do všech italských regionů, což bylo původním cílem pořadatelů závodu. Tento sen organizátorů se nepodařilo uskutečnit $\mathrm{v}$ důsledku nutnosti „[...] zkombinovat průměrnou délku etap okolo 170 kilometrů, italskou geografii, historii a také komerční zájmy [...]“ (Cycling News, 2017). Čtyři z italských regionů musely být posléze vynechány. I tak se dle ředitele závodu podařilo, aby Giro navštívilo „[...] některé z nejkrásnějších částí Itálie. Myslím si, že máme pravdu, když popisujeme Giro d'Italia jako nejtěžší závod na světě na nejkrásnějším místě světa" (Vegni cit. dle Farrand, 2016). Závod také nezůstal pouze na území Itálie, nebot během šestnácté a zároveň královské etapy s dvojitým výjezdem na Stelvio bylo nutné udělat odbočku trasy na několik kilometrů do sousedního Švýcarska. Jednalo se však o jedinou chvíli, kdy peloton v roce 2017 Itálii opustil, prričemž v posledních letech pravidelně některé $\mathrm{z}$ etap končily či začínaly mimo italskou půdu. V předchozích šesti ročnících Gira se hned čtyřikrát i jeho zahajovací etapa uskutečnila v zahraničí. ${ }^{15}$

Společně s př́rodními krásami Itálie jsou fanouškům u televizních obrazovek, internetových streamů či přímo v místě závodu prezentovány také kulturní památky Itálie a historie, která se $\mathrm{k}$ nim přímo váže. Některé $\mathrm{z}$ památek $\mathrm{v}$ místech, kterými měl stý ročník závodu procházet, na tuto skutečnost upozornily již sto dnů před startem Gira, nebot byly zbarveny světly dorůžova (Giro d'Italia, 2017b). Jednalo se např. o Neptunovu fontánu stojící od 16. století ve Florencii, katedrálu ve městě Molfetta, již dříve zmiňovaný památník věnovaný Fausto Coppimu na Stelviu nebo monument v Reggio Calabria odkazující na Viktora Emanuela II., prvního panovníka sjednocené Itálie. Modernější tvář Itálie následně ukazovaly růžové ledové sochy v horských průsmycích nebo obdobně zbarvená hlavní tribuna na motoristickém okruhu v Monze, kam cyklisty zavedla poslední etapa závodu. Jeho vyvrcholení se konalo před gotickým Milánským dómem (Duomo di Milano), jehož stavba započala již koncem 14. století. „Bylo pro nás důležité, aby stý ročník končil blízko centra Milána, na Piazza Duomo a jediný způsob, jak toto uskutečnit, bylo časovkou jednotlivcư“ (Vegni cit. dle Farrand, 2016; kurzíva dodána). Dojezd celého pelotonu před tento chrám byl totiž nereálný a pořadatelé se nechtěli vzdát možnosti zakončit jubilejní závod u jedné z největších katedrál světa. Obrázky vítěze závodu Toma Dumoulina v růžovém dresu za zády s Milánským dómem se objevily prakticky ve všech médiích, které o stém ročníku Gira d'Italia informovaly.

Nejenom těmto památkám, ale mnohým dalším se věnovali komentátoři přímých přenosů ze závodu či se objevovaly alespoň na fotografiích doprovázejících reportáže z jednotlivých etap apod.

\footnotetext{
${ }^{15} \mathrm{~V}$ roce 2010 Giro d'Italia startovalo v nizozemském Amsterodamu, o dva roku později v Dánsku ve městě Herning, v roce 2014 prrivítal začátek Gira severoirský Belfast a naposledy - v roce 2016 - viděli start závodu opětovně Nizozemci, tentokrát v Apeldoornu.
} 
Představení kulturních památek, míst historie i tamní přírody tedy nemělo úlohu pouze směrem k Italům sledujícím závod, ale miřilo i za italské hranice. Cyklistické závody okolo určitého území v současné době dávají př́ležitost domácímu státu prezentovat se zahraniční veřejnosti jako místo, které má určité kouzlo, a tak by ho ideálně měli chtít ti, co sledují v tomto případě Giro d’Italia, navštívit. Ostatně i tuto funkci závodu jednoznačně přiznává Mauro Vegni: „Giro d’Italia pomáhá propagovat Itálii a všechny skvělé věci, které Itálii celosvětově proslavily. Myslím si, že naší výzvou do budoucna je pomoci propagaci Itálie jako místa k návštěvě, udělat reklamu její kultuře, jídlu a věcem, jako jsou náš design a styl“ (cit. dle Farrand, 2016). Je tedy možné říci, že závod okolo Itálie je vhodným nástrojem italské sportovní diplomacie ${ }^{16}$ a sportovní akce, kterým se dostává mezinárodní pozornosti, jsou „,[...] mnohými vládami viděny jako ideální způsob, aby byla představena [pořadatelská] země, její města a lidé světu jako atraktivní destinace pro cestování a investice" (Pigman 2014: 100).

Sledovanost stého ročníku Gira poté dává napovědět, že si za léta existence závod okolo Itálie opravdu získal pozornost i ze strany zahraniční veřejnosti. Televizní záběry z ročníku 2017 byly dle informací z oficiálních internetových stránek závodu vysílány prakticky ve všech zemích světa, celkově právě výše zmíněné internetové stránky navštívilo okolo 125 miliónů uživatelů (Giro d'Italia, 2017d). Nepř́ímo společně s výsledky, analýzami a rozhovory spojenými se samotným závodem putovaly i $\mathrm{k}$ zahraničním fanouškům ( $\mathrm{k}$ některým $\mathrm{z}$ nich více, $\mathrm{k}$ jiným méně) zprávy o tom, jak krásnou zemí Itálie je.

\section{ZÁVĚR}

Závod v silniční cyklistice Giro d’Italia během více než sta let své existence získal obrovskou pozornost ze strany fanoušků nejenom na Apeninském poloostrově. Samotné konání tohoto sportovního klání napomáhá formovat a obnovovat italskou identitu u jejich (potenciálních) nositelů, přičemž tento prvek byl dle mnohých pozorovatelný již od prvního ročníku Gira, který se uskutečnil v roce 1909. Na tuto skutečnost jsem se snažil upozornit na př́kladu stého ročníku, kdy se pořadatelé pokoušeli o to, aby Giro, které je dle nich „dědictvím všech Italů“ (Bellino cit. dle Tomíček, 2017, s. 130), bylo co nejvíce italské.

Nepřímo tedy můžeme říci, že obzvlášś tento ročník měl klást o poznání větší důraz na identitu domácích fanoušků, kteří ho sledovali, čemuž se pořadatelé snažili napomoci samotnou trasou závodu. Ta procházela místy důležitými pro italskou společnost, a proto sté Giro „nemohlo“ začínat - v odkazu na Giuseppe Garibaldiho - jinde než na Sardinii. Peloton měl v ideálním př́padě navštívit co největši množství italských regionů a naopak oproti předchozím letům se s výjimkou několikakilometrového intermezza ve Švýcarsku pohyboval pouze po silnicích Itálie. Některé z etap byly organizátory zvoleny tak, aby připomínaly italské cyklistické hrdiny, na které by se nemělo zapomenout. Jednalo se zejména o Gina Bartaliho, jeho rivala Fausta Coppiho a legendu konce 90. let Marca Pantaniho. Potenciálních podnětů, které by mohly Italům napomoci v obnovování jejich národní identity, pořadatelé závodu připravili dostatečné množství. Již samotná existence Gira d'Italia je fakticky jedním z nich.

Zároveň tyto zprávy nemiří pouze směrem k italskému publiku, ale směřují prakticky od dob existence závodu také $\mathrm{k}$ zahraničním sportovním fanouškům. Připomeňme např̀. pozitivní vnímání výkonů Bartaliho a Coppiho na Tour de France, které bylo nepř́ímo spojeno s pozitivnějším pohledem na poválečnou Itálii (Cardoza, 2010, s. 372). V současné době v důsledku širokého

\footnotetext{
${ }^{16}$ Pod sportovní diplomacií rozumějme využivání „[...] sportovců a sportovních událostí, aby upoutali, informovali a u zahraniční veřejnosti a organizací vytvářeli příznivou image, aby tvarovali jejich percepce tím způsobem, který [více] napomáhá [...] vládním zahraničněpolitickým cílům“ (Murray, 2012, s. 581).
} 
mediálního pokrytí závodu, kdy je možné o něm získávat kvalitní informace i na druhém konci světa, než se koná, se taktéž otevírá o poznání větší prostor pro snahy „prodat“ ho i do zahraničí, což by v ideálním případě mělo přinést pozitivní vnímání ze strany celosvětové veřejnosti nejenom pro tento cyklistický podnik, ale opětovně pro Itálii jako celek. Je tedy možné ŕíci, že Giro d'Italia je velmi cenným nástrojem italské sportovní diplomacie.

\section{Literatura}

Anderson, B. (1991). Imagined Communities. Reflections on the Origin and Spread of Nationalism. London - New York: Verso. Anderson, B. (2003). PomysIná společenství. In Hroch, M. ed, Pohledy na národ a nacionalismus. Čítanka textů (s. 239-269). Praha: Sociologické nakladatelství.

Billig, M. (1995). Banal Nationalism. London - Thousand Oaks - New Delhi: Sage Publications.

Blickensdörfer, H. (1985). Sůl v kávě. Praha: Svoboda.

Cardoza, A (2010). ,Making Italians?' Cycling and national identity in Italy: 1900-1950. Journal of Modern Italian Studies, 15(3), 354-377.

Clark, M. (1996). Modern Italy. 1871-1995. London: Longman.

Cronin, M. \& Mayall, D. (2005). Sport and Ethnicity: some introductory remarks. In Cronin, M. \& Mayall, D. eds., Sporting Nationalisms: Identity, Ethnicity, Immigration and Assimilation (s. 2-14). London - Portland: Frank Cass.

Crutchley, P. (2014). Gino Bartali: The cyclist who saved Jews in wartime Italy. BBC, 9. 5. 2014. Dostupné z http://www.bbc. com/news/magazine-27333310.

Cycling News (2017). Giro d'Italia 2017: The essential guide. Dostupné z http://www.cyclingnews.com/giro-ditalia/preview.

Cycling Weekly (2017). Giro d'Italia. Dostupné z http://www.cyclingweekly.com/news/racing/giro-ditalia.

Farrand, S. (2016). Giro d'Italia 2017: 'Whoever doesn't ride will miss out on a special race' says director Vegni. Cycling News, 25. 10. 2016. Dostupné z http://www.cyclingnews.com/news/giro-ditalia-2017-whoever-doesnt-ride-will-miss-outon-a-special-race-says-director-vegni/.

Fisher, S. (2017). Santini Capsule Collection jerseys honor the Giro d'Italia's 100 year history. Bike Rumor, 5. 5. 2017. Dostupné z https://www.bikerumor.com/2017/05/05/santini-capsule-collection-jerseys-honor-the-giro-ditalias-100-year-history.

Foot, J. (2011). Pedalare! Pedalare! A History of Italian Cycling. London: Bloomsbury.

Giro d'Italia [@giroditalia] (2016a). Celebriamo Gino Bartali nella sua Ponte a Ema a 17 anni dalla morte We celebrate Bartali in his born town 17 years after his death \#Giro100 [tweet], 25. 10. 2016. Dostupné z https://twitter.com/giroditalia/ status/790956366097768448.

Giro d'Italia (2016b). Giro 100: Sardinia to Host the Big Start, 14. 9. 2016. Dostupné z http://www.giroditalia.it/eng/news/ il-giro-100-partira-dalla-sardegna.

Giro d'Italia (2016c). Giro d'Italia 2017 - La storia di 100 edizioni, 25. 10. 2016. Dostupné z https://www.youtube.com/ watch?v=e22elgM2GQ4.

Giro d'Italia [@giroditalia] (2017a). Castellania: Fausto and Serse Coppi's historic house museum \#giro100 [tweet], 20. 5. 2017. Dostupné z https://twitter.com/giroditalia/status/865889180219564032.

Giro d'Italia (2017b). Italy Turns Pink to Celebrate Giro100, 27. 1. 2017. Dostupné z http://www.giroditalia.it/eng/news/ litalia-del-giro100-si-e-illuminata-di-rosa.

Giro d'Italia [@giroditalia] (2017c). Mario Cipollini ottenne l'ultimo dei suoi 42 successi al Giro il 19 maggio 2003 a Montecatini \#Giro100 [tweet], 19. 5. 2017. Dostupné z https://twitter.com/giroditalia/status/865562468965388288.

Giro d'Italia (2017d). The Numbers of the Giro 100, 30. 5. 2017. Dostupné z http://www.giroditalia.it/eng/news/i-numeridel-giro-ditalia-100.

Giro d'Italia Official Store (2017). Poster Formiche Giro d'Italia 2017. Dostupné z https://www.all4cycling.com/shop/posterformiche-giro-ditalia-2017-pm-129658.html.

Guttmann, A. (1978). From Ritual to Record. The Nature of Modern Sports. Columbia New York: University Press.

Hobsbawm, E. (2000). Národy a nacionalismus od roku 1780. Program, mýtus, realita. Brno: Centrum pro studium demokracie a kultury.

Kratochvíl, J. (2009). Jak cyklista báječným triumfem na Tour zažehnal neklid v Itálii. iDNES, 1. 7. 2009. Dostupné z http://sport. idnes.cz/jak-cyklista-bajecnym-triumfem-na-tour-zazehnal-neklid-v-italii-ps6-/cyklistika.aspx?c=A090630_221002_ sporty_par.

López, B. (2010). Sport, Media, Politics and Nationalism on the Eve of the Spanish Civil War:The First Vuelta Ciclista a España. The International Journal of the History of Sport, 27(4), 635-657.

McGann, B. McGann, C. (2006). The Story of The Tour de France. How a Newspaper Promotion Became the Greatest Sporting Event in The World. Volume 1: 1903-1964. Indianopolis: Dog Ear Publishing.

Montali, A. ed. (2017). I/ Garibaldi: Giro d'Italia 100. Dostupné z http://static2.giroditalia.it/wp-content/uploads/2017/04/ Garibaldi_2017.pdf.

Monti, A. (2017). 100 è un numero magico / 100 is a Magic Number, In Montali, A. ed., Il Garibaldi: Giro d'Italia 100 (s. 4-5). Dostupné $z$ http://static2.giroditalia.it/wp-content/uploads/2017/04/Garibaldi_2017.pdf.

Murray, S. (2012). The Two Halves of Sports Diplomacy. Diplomacy \& Statecraft, 23(3), 576-592. 
O'Brien, C. (2017). Giro d'Italia: The Story of the World's Most Beautiful Bike Race. London: Pursuit Books.

Pigman, G. A. (2014). International Sport and Diplomacy's Public Dimension: Governments, Sporting Federations and the Global Audience. Diplomacy \& Strategy, 25(1), 94-114.

Pivato, S. (1990). The Bicycle As a Political Symbol: Italy, 1885-1955, The International Journal of the History of Sport, 7(2), 173-187.

Pivato, S. (1996). Italian Cycling and the Creation of a Catholic Hero: The Bartali Myth. In Holt, R. \& Mangan, J. A. \& Lafranchi, P. eds, European Heros. Myth, Identity and Sport (s. 128-138). Portland: Frank Cass.

Ronchi, M. \& Josti, G. (2007). Marco Pantani. Muž v úniku. Praha: Triton.

Thiessová, A. M. (2007). Vytváření národních identit v Evropě 18. až 20. století. Brno: Centrum pro studium demokracie a kultury.

Tomíček, M. (2017). Centenario. Po stopách historie. 53x11, 10(3), 130-133.

\section{Kontakt na autora:}

Jiři Zákravský

Katedra politologie a mezinárodních vztahů FF ZČU

Jungmannova 1

Plzeň

30100

jirkazak@kap.zcu.cz 
Příloha č. 1: Trasa stého ročníku Giro d'Italia

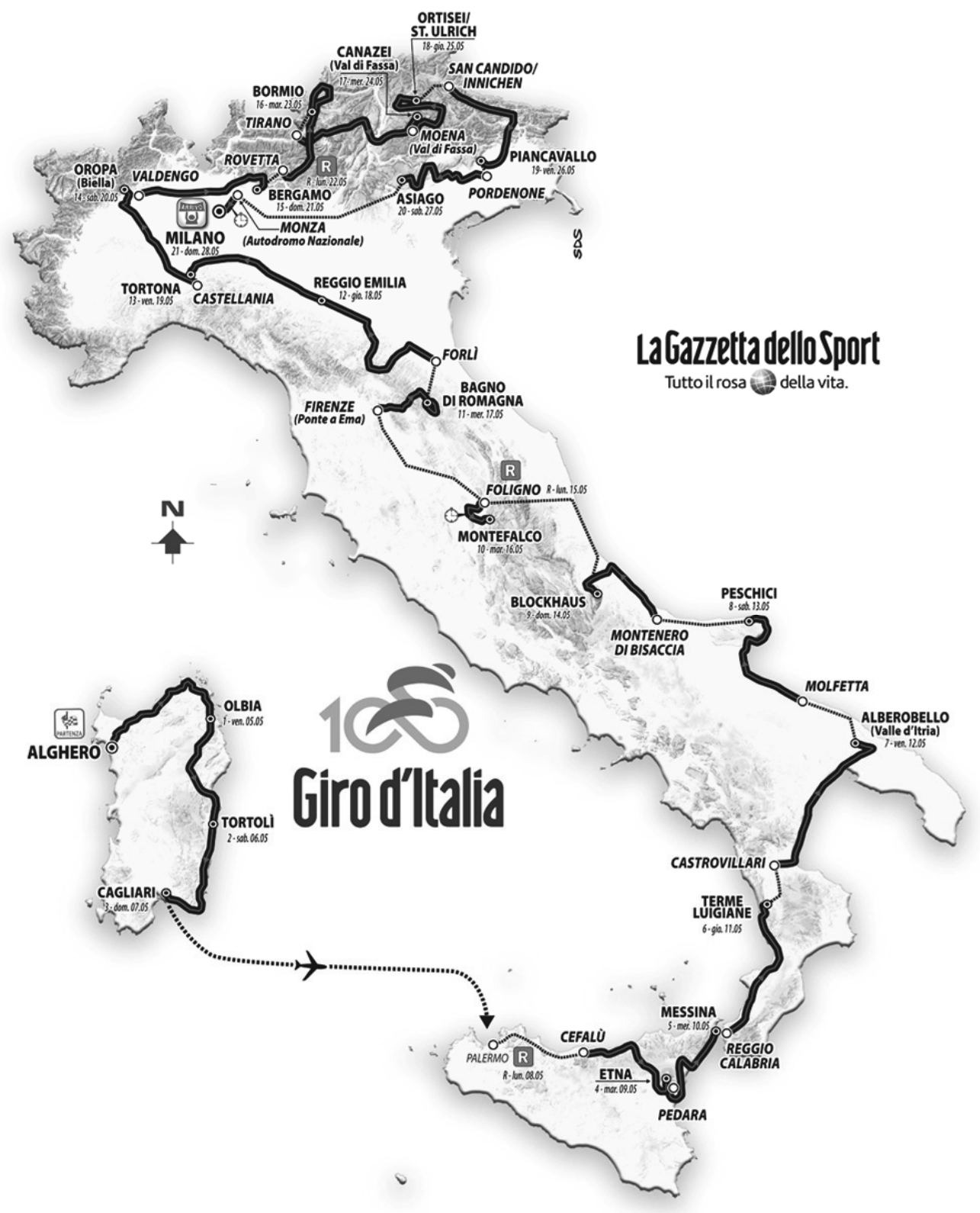

Zdroj: Cycling Weekly (2017). Giro d’Italia. Dostupné z http://www.cyclingweekly.com/news/racing/giro-ditalia. 